\title{
COVID'S EFFECT ON AN ENDANGERED LANGUAGE IN THE SYLHET AREA OF BANGLADESH
}

\author{
Snehangshu Shekhar Chanda \\ Sylhet Agricultural University, Sylhet. Bangladesh
}

\begin{abstract}
Language is the way of communication and used in different aspects of life. In every country there is a national language which is the state language used in offices and different organizations. Bengali is the state and widely spoken language of Bangladesh however language varies from community to community, race to race, society to society This study shows that there are many indigenous languages in Bangladesh which may be endangered in future specially in the Sylhet area of Bangladesh. The Manipuri language which is not used officially in Bangladesh may be one such language. It has its own alphabets and is spoken in the community. The language has however not been hampered due to COVID 19 and in fact has become more popular during the lockdown. Due to the increase in the popularity of social media (face book group, Cheik Kheik) the Manipuri language in Sylhet, still maintains their ethnic culture and use their language in the home domain.
\end{abstract}

Key words: Language, Manipuri, Endangered, COVID 19, Bangladesh, Sylhet.

\section{INTRODUCTION}

An endangered language is a language which is at risk of falling out of use as its speakers die or shift to other languages. A dead language may still be studied through recordings or writings, but it is still dead or extinct unless the language is used. Languages have always become extinct throughout human history. In fact, it seems that they are currently dying at an accelerated rate due to globalization, imperialism, neocolonialism and linguicide. When a language has no more native speakers, it becomes a dead language. A dead language is 'one that is no longer the native language of any community even if it is still used in other context' (Brenzinger,Matthias1992). "" If no one can speak the language at all, it becomes an "extinct language". A language may also lack important factors that contribute to its survival such as an alphabet, a body of literature, and people who read and write it. (Ethnologue). The diversity of language provides diverse way of comprehending experience and this is necessary to our survival and species and that vanishing languages need to be protected just as vanishing species.(Lakoff;1987-337).The survival of a language is also threatened when speakers move to other areas where different languages are spoken, or when government policies promote the use of a specific language in school, official business and the media.

\section{Background and Research Objectives}

Potential endangerment is the first step towards language death. Sometimes it seems that a language faces strong external pressure. In this case there might still be communities of speakers who pass the language on to their children. When a language has reached the endangerment stage, there are only a few speakers including children who are not learning the language. During this stage of language extinction the language is seriously endangered. The language is unlikely to survive another generation and will soon be extinct.( https://en.wikipedia.org/wiki/Endangered_language) The fourth stage is moribund, followed by the fifth stage extinction. Krauss (1992) estimated that 90 percent of the world's language would be severely endangered or dead by 2100. Nettle and Romaine (2000) provide a more optimistic estimate stating that half of the world's languages will be lost. The statistics shows the most spoken languages worldwide in 2019 were around 1.27 billion people who spoke English either natively or as a second language, slightly more than the 1.12 billion Mandarin Chinese speakers at the time of survey, Bengali is spoken by 265 millions people.(Source; Erin Duffin, 2020).

There is no authentic record about the number of endangered languages in Bangladesh as different sources have reported different figures regarding the number of endangered languages. The number of individual languages listed for 
Bangladesh is 41 and all are living languages in which 36 are indigenous and 5 are non-indigenous. Furthermore, four are institutional, twelve are developing, sixteen are vigorous and nine are in trouble.(Combell and King-2011). In the Sylhet area there are a number of indigenous languages which might or might not be endangered. One of these languages is the Manipuri Language which is the regional language spoken in the Sylhet area of Bangladesh.

Corona virus -COVID-19 is an infectious disease caused by severe acute respiratory syndrome corona virus 2 (SARSCoV-2). It was first identified in December 2019 in Wuhan, Hubei, China, and has resulted in an ongoing pandemic. The people of Bangladesh have experienced the lockdown process and have been staying at home during the lockdown. Covi19 has politically and culturally changed the world.

The study was undertaken to determine the status of the Manipuri Language in the Sylhet area in Bangladesh and to find out if COVID19 has had an effect on sociocultural activities and the use of the Manipuri language.

\section{Methodology}

The study was conducted from January 2020 to May 2020. Due to the lockdown and restrictions of movement a total of 30 Manipuri professionals and non-professionals were interviewed by telephone. They were asked about the use and status of the Manipuri language. The language used in Facebook was also sourced to determine the language used. Photographs of areas where Manipuri speakers reside were also taken.

\section{Results:}

\section{A. The Languages of Bangladesh:}

Bangla is the official and state language of Bangladesh and is used in every sphere of life. The people of the nation protected Bangla from the clutches of the Pakistani oppressors in 1952 by preventing Urdu from being the state language of East Pakistan where a vast majority of people spoke in Bangla. Many young people sacrificed their lives for their mother tongue on 21st February 1952 which later became known as International Mother language day by UNESCO.There are other minority languages, regional languages and foreign languages and the people of each community are free to speak their own language (see Table 1).

\begin{tabular}{|c|c|c|}
\hline 1 & $\begin{array}{l}\text { Official } \\
\text { language }\end{array}$ & Bangla \\
\hline 2 & $\begin{array}{l}\text { National } \\
\text { language }\end{array}$ & Bangla \\
\hline 3 & $\begin{array}{l}\text { Regional } \\
\text { languages }\end{array}$ & $\begin{array}{l}\text { Unofficial Chittagonian, Sylheti, } \\
\text { Chakma, Rangpuri }\end{array}$ \\
\hline 4 & $\begin{array}{l}\text { Minority } \\
\text { languages }\end{array}$ & $\begin{array}{l}\text { Manipuri, Hajong, Tangchangya, } \\
\text { Sadri, Khasi, Koda, Mundari, Pnar, } \\
\text { Santali, War-Jaintia, Kurukh, Sauria } \\
\text { Paharia, A'Tong, Chak, Chin, Asho, } \\
\text { Bawm, Falam, Haka, Khumi, Koch, } \\
\text { Garo, Megam, Mizo, Mru, Pangkhua, } \\
\text { Rakhine/Marma, KokBorok, Riang, } \\
\text { Tippera and Usoi }\end{array}$ \\
\hline 5 & $\begin{array}{l}\text { Main } \\
\text { immigrant } \\
\text { languages }\end{array}$ & Bihari $\bullet$ Burmese $\bullet$ Rohingya \\
\hline 6 & $\begin{array}{l}\text { Main } \\
\text { foreign } \\
\text { language }\end{array}$ & English \\
\hline
\end{tabular}

\section{B. The Language in Sylhet}

Sylhet is situated on the north-eastern part of Bangladesh and different groups of indigenous people live in Sylhet. Sylheti is an eastern Indo-Aryan language which is spoken mainly in the Sylhet region of Bangladesh, and the neighboring Barak Valley in the Indian state of Assam. There are also speakers of Sylheti in the Indian states of Meghalaya, Tripura and Manipur, as well as in the USA and UK. In 2007 there were about 11 million speakers of Sylheti.( Snehangshu -2018) There are also some languages known as Manipuri Monipuri,Khasia,Sadri and other languages. Manipuri is one of the most widely spoken language among the Manipuri communities in the Sylhet area of Bangladesh.

The present Manipuri community in Bangladesh is divided into two groups; Bishnupriya and Meitei, the former language is seen as an Indo-Aryan language. Researchers like Dr. 
Kaliprasad Singha state that the language is in the borderline of Magadhi-Prakrit language. Some have even tried to establish it as a Shauraseni-Prakrit language. In Bishnupriya Manipuri language, the verb changes according to gender and number. For example-

In case of Gender and number language may be different.

Thoiba is going - Thoiba Jarga(Male)

Thoibi is going - Thoibi Jeiriga( Female)

\section{Difference is number}

I am going - MiJauriga

We are going - Ami Jaranga

"No" usually comes before the verb to establish significance, like; I am not going - Mi Na Jimga. According to Suvasish Singha, (2012) there are few gasping phonetics in the language.

\section{The Status of Manipuri Monipuri Language in Bangladesh}

Manipuri Language is used as the regional and spoken language of the Manipur speech community in Bangladesh. This language has its own alphabet and this is an important identity marker (see Table 2). In Table 3 we show some phrases in Manipuri and Table 4 provides data of the language obtained by one of the researchers.

Table 2: Manipuri Alphabet

(Source: https://omniglot.com/writing/manipuri.htm, Literature ManipuriMonipuri)

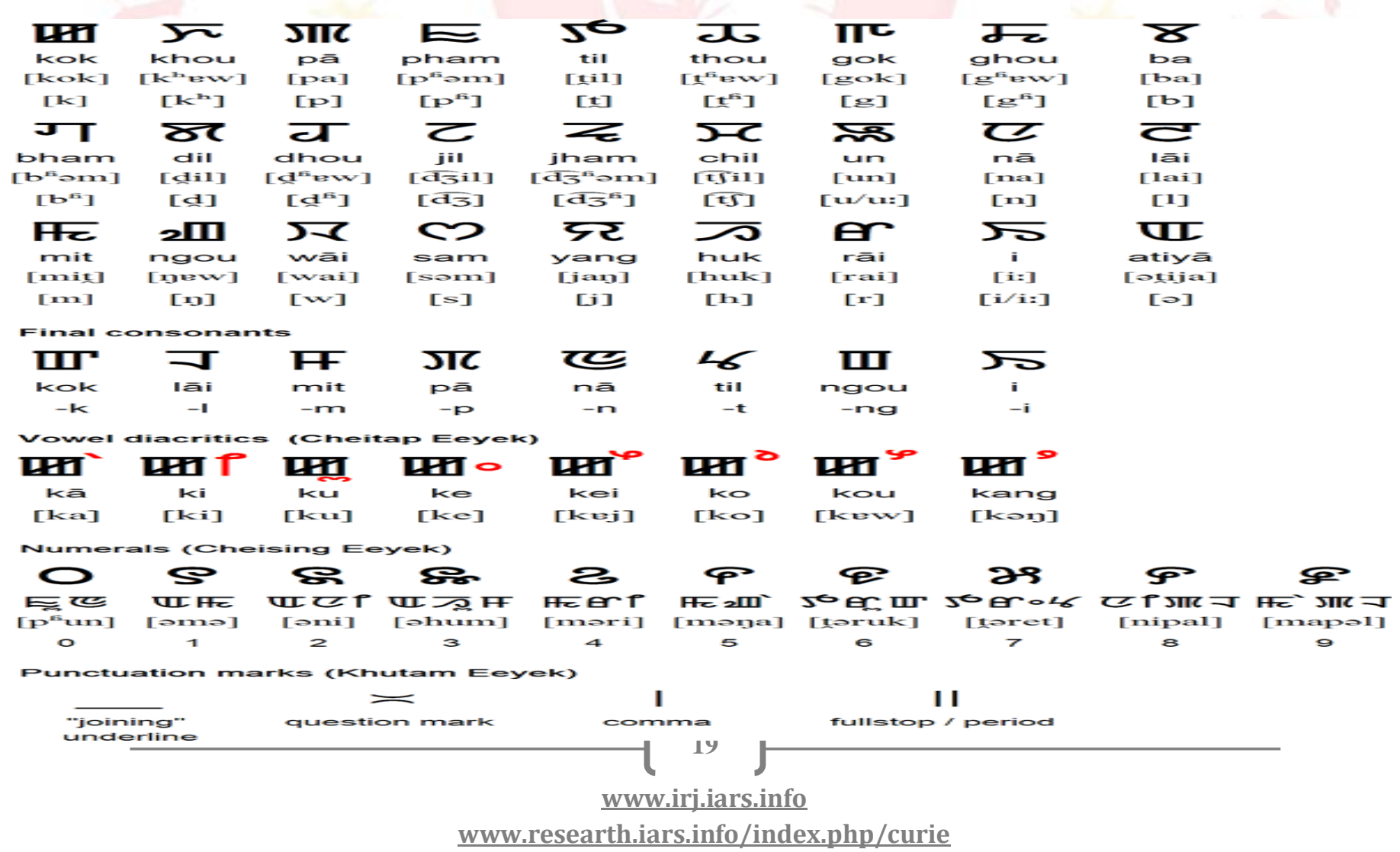




\section{Yimternational Research Journal}

p-ISSN 2202-2821 e-ISSN 1839-6518 (Australian ISSN Agency)

The following table shows different sentences written in Bengali and Manipuri with English translation:

Table 4: Sentences in Bengali and Manipuriwith English translations (Interview by Asutosh Singha, Assistant Professor, Sylhet Agricultural University)

\begin{tabular}{|c|c|c|}
\hline Bengali & ManipuriMonipuri & English \\
\hline Tomarnamki? & Tor nanghankihan? & What is your name? \\
\hline Amar namMili. & MornanghanMili. & My name is Mili. \\
\hline Tomar baba kikoren? & Tor baba kitakorer go? & What does your father do? \\
\hline Ami basaijabo. & Me gore jitouga. & I will go to my house. \\
\hline Apnikikhaben? & Ti kitakhaitei go? & What will you eat? \\
\hline Amar kharaplagse. & Mortalungeina lager. & I feel unwell. \\
\hline Tomarokhanejetehobe. & Tortaohotjanalagtoi. & You have to go now. \\
\hline Tumikikorcho? & Ti kitakororhan? & What are you doing? \\
\hline Tumikothaiparashunakoro? & $\begin{array}{l}\mathrm{Ti} \\
\text { kuranglerictamkoruri? }\end{array}$ & Where do you study? \\
\hline Bairejeteichsekorse. & Bare janaaher. & I wish to go outside. \\
\hline Bristi pore. & Bororporer. & It is raining. \\
\hline Azkibar? & Aziki din? & What day is it today? \\
\hline Eta amarkhubposondo. & Eta me jobormonauri. & I like it very much. \\
\hline Tumikothaigiechile? & Ti kuranggiachilehan? & Where did you go? \\
\hline Azekta gas lagabo. & Azisopaahanlagiut. & Today, I will plant a tree. \\
\hline Ami hatsi. & Me aturi. & I am walking. \\
\hline Bairebatasboise. & Bare bou der. & Air is blowing outside. \\
\hline Agunthekedurethakbe? & Jobigattaduri yea thaish. & Keep a distance from fire. \\
\hline Tomrasukhetheko. & Tumi lungi yea thaio. & You live in peace. \\
\hline Aztaholeashi. & Aziohatteahonga. & Let me come. \\
\hline Tumikadso keno? & Ti kidiakadurita? & Why are you crying? \\
\hline Tomar ma tomakedakse? & Tor imai tore dakhiri. & Your mother is calling you. \\
\hline $\begin{array}{l}\text { Ami } \\
\text { dadurkasegolposhunbo. }\end{array}$ & $\begin{array}{l}\mathrm{Me} \\
\text { baparangtouarihuntou. }\end{array}$ & $\begin{array}{l}\text { I will listen to a story from } \\
\text { my grandfather. }\end{array}$ \\
\hline Ekdesheek Raja chilo. & Deshahat raja ago asilta. & $\begin{array}{l}\text { There was a King in a } \\
\text { country. }\end{array}$ \\
\hline Tara anondokorse. & Tangiharoupakortara. & They are enjoying. \\
\hline Matribhashabechethak. & Imartharpungchipalok. & $\begin{array}{l}\text { May mother tongue live } \\
\text { long. }\end{array}$ \\
\hline
\end{tabular}

The Manipuris speak the language at home with their family members and with other members of their speech community. However, during any national function Bengali is used. Since there is no scope to teach their language in educational institutions, they learn the language at home. Nowadays, the Manipuris are multilingual and bilingual. Educated Manipuris are multilingual because they know three languages, Bengali and Manipuri and English. When they meet at a gathering a diglossic situation is created. They are free to speak in Manipuri and are also proficient in English and Bengali. When speaking in Bengali and English the Manipuri sound system is used. Other Manipuris are bilingual because they know Bengali and Manipuri.

The community has shown an interest in using their alphabet on banners (see Figure 1). The cultural heritage of the community is rich and should be preserved and celebrated. A number of books and brochures have been published in the Manipuri language in Bangladesh. In neighboring India, in the state of Manipur, academic books are published in Manipuri A Manipuri language course should be introduced in different universities in Bangladesh perhaps under an Institute of Modern Language or a Department of Language/s.. Furthermore, in several universities in India it is possible to pursue a M.Phil/PhD in ancient Manipuri language and literature.

In front of the Handloom Factory of the Manipuri Community,

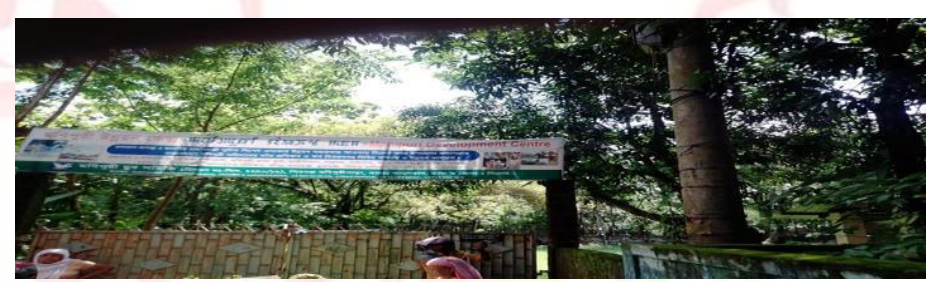

Figure 1: A banner in Manipuri Alphabets.

The community is culturally rich as seen in texts in the language. In the 18th century, during the reign of King GaribNewaj, Bengali Hinduism, and later GaudiyaVaishnavism began to infiltrate Manipur. From then, Manipuris began to translate various Sanskrit literatures and religious books, and this accelerated the trend of religious literature. The divine and earthly relationship of Madoi and Soralel (soul) and their conflict is expressed in various ways through the appeal of Madoi. An ancient pattern is noticeable in the language, word and sentence structure.

Falguni Singha, a social worker edited a magazine called Jagaran in 1925 and the age of Monipuri literature began. The magazine published articles both in the Bishnupriya and Meitei languages. The Surma Valley Manipuri Society was established, later in 1934 renamed Surma Valley Manipuri Association and the members included the Meiteis, the Bishnupriyas and the Pangals (Manipuri Muslims). From 1933 onwards there were a number of journals in Manipuri (1933), Mekhali (1938) and Kshatryajyoti (1944) etc. which fostered literary and cultural activities and nationalism. 
In modern Bishnupriya Manipuri Literature, there were a number of poets, dramatists, short story writers and essayists (see Table 5).

Table 5: Authors and Books

\begin{tabular}{|l|l|}
\hline Name of the Author & Book \\
\hline AswinikumarSingha & Harish Chandra, sabitriSatlyaban \\
\hline IndrakumarSingha & Haribola-Ehari,KailasLailat \\
\hline SudhanvaSingha & ManurKothaiGor Na Bagyo \\
\hline
\end{tabular}

In Bangladesh, the history of Manipuri literature took a new turn in 1975 after the formation of 'Bangladesh Manipuri Sahitya Sangsad' and publication of Manipuri literary magazine Dipanvita. In addition, an irregular Journal (MEIRA) is published by the Bangladesh Manipuri Sahitya Sangsad. Many other Manipuri organizations have also been publishing literary journals such as Epom, Shajibu, Mitkapthokpa and Khollao. In 1982, a book of Manipuri poems (Basanta Kunnipalaji Leibang), the first on poems in Bangladesh was published by Bangladesh Manipuri Sahitya Sangsad, In 1990, it published another book Bangladesher Manipuri Kabita containing 20 Manipuri poems of 10 selected Manipuri poets in Bangladesh. Subsequently, 2 other books of Manipuri poems Myang Mapei Marakta and Wakhalji Nachom were published. Some books on Manipuri subjects have also been published in the Bengali language.

Manipuri culture has a rich and colorful tradition. Dance and music play a vital role in the life of the Manipuri community. A flourishing branch of Manipuri culture is dance. The Manipuri synonym of dance is jagoi and in this dance, body movements are either in the form of a circle or an ellipse. A well-known dance is the Rasa dance innovated by Maharaj Bhagyachandra and it was first performed in Manipur in 1779 during the full moon of Kartik. Variations of Manipuri dance can be grouped into two broad classes: folk dance and shastriya or classical dance. Manipuri folk dance includes Laiharaoba, Khamba-Thoibi, MeibiJagoi and LeishamJagoi, while Rasa, Gosthaleela, Udukhol and Mridanga fall under the classical group. Manipuri dance (see Figure 2) was brought to the horizon of the outside world by Rabindranath Tagore, who first witnessed the dance in a visit to Sylhet in 1919. Soon after that, he introduced teaching of the dance at Santiniketan.

Many Manipuris now also follow the teachings of Islam and are known as Meitei Pangon or Manipuri Muslims. Rites, rituals and beliefs are part and parcel of the day to day life of the Manipuris, regardless of religion. They observe special religious ceremonies and customary rituals on major occasions of life such as births, marriages and death.
Culinary dishes are also part of the culture of the Manipuris. The names of Manipuri dishes (see Table 6) are different from Bangladeshi dishes and are also cooked in different ways.

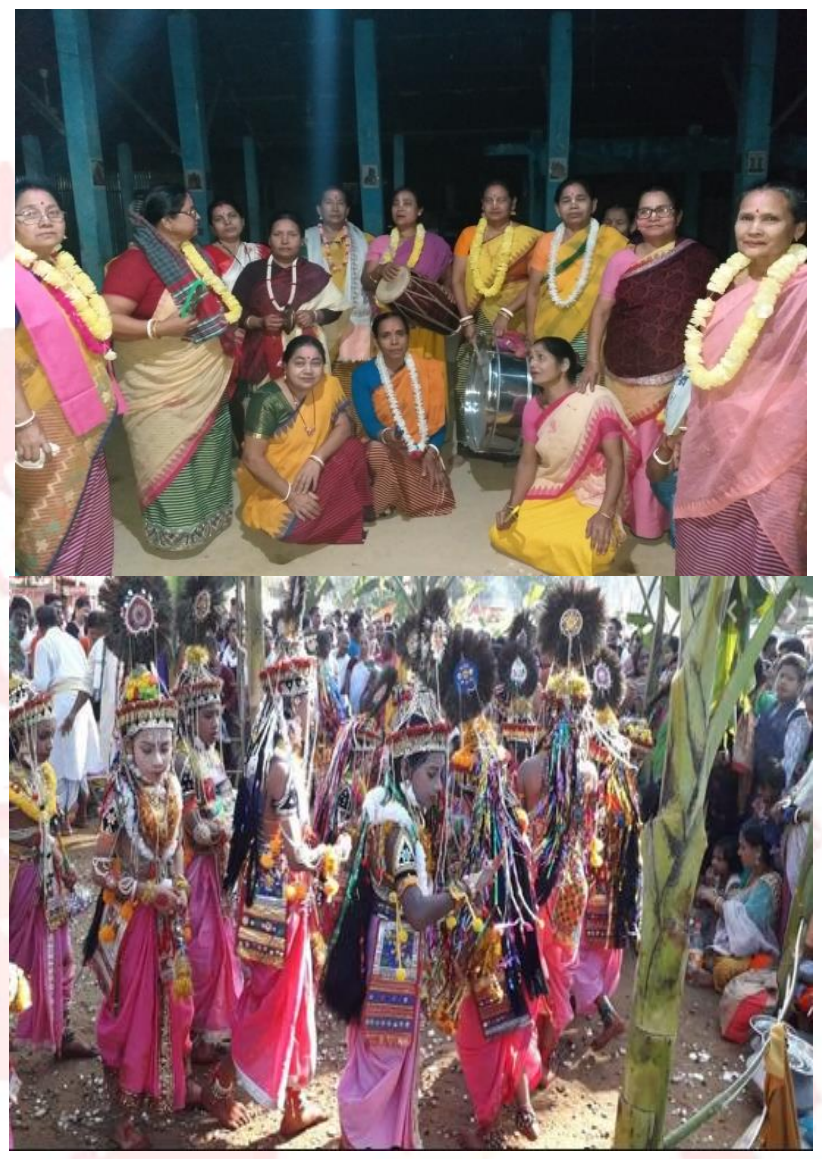

Figure 2: Manipuri Dance

At night the Manipuri people prefer to eat NunciHojok prepared with potato, dry fish,dried fish oil with a lot of water.

The effect of COVID on Manipuri language and Culture:

Covid-19 is an infectious disease caused by coronavirus and the infection rate of corona virus is very high but the fatality rate is low. In European Countries and in the USA the death rate is high. This virus can attack and affect different vital systems of our body. People with Pneumonia, Asthma, Heart Disease, Diabetes and Kidney Disease are the main victims to face complications from Covid-19. Coronavirus is transmitted through the mouth, nose and eyes. Corona is a global crisis. 215 countries around the world have reported a total of $8,506,107$ confirmed cases of the Covid-19 and a death toll of $455,231(5.35 \%$ ) deaths. (Updated on 20.06 .20 by WHO) DGHS has reported a total of 108,775 confirmed cases and a death toll of 1,425 (1.3\%) deaths in Bangladesh.

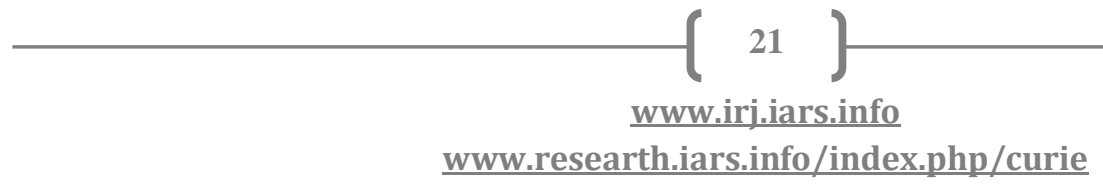




\section{Yinternational Research Journal}

p-ISSN 2202-2821 e-ISSN 1839-6518 (Australian ISSN Agency)

Table 6: Name of Manipuri Foods (Courtesy::AsutoshSingha, Assistant Professor, Taposh Kumar Singha,Deputy, Director,Sylhet Agricultural University and other researchers)

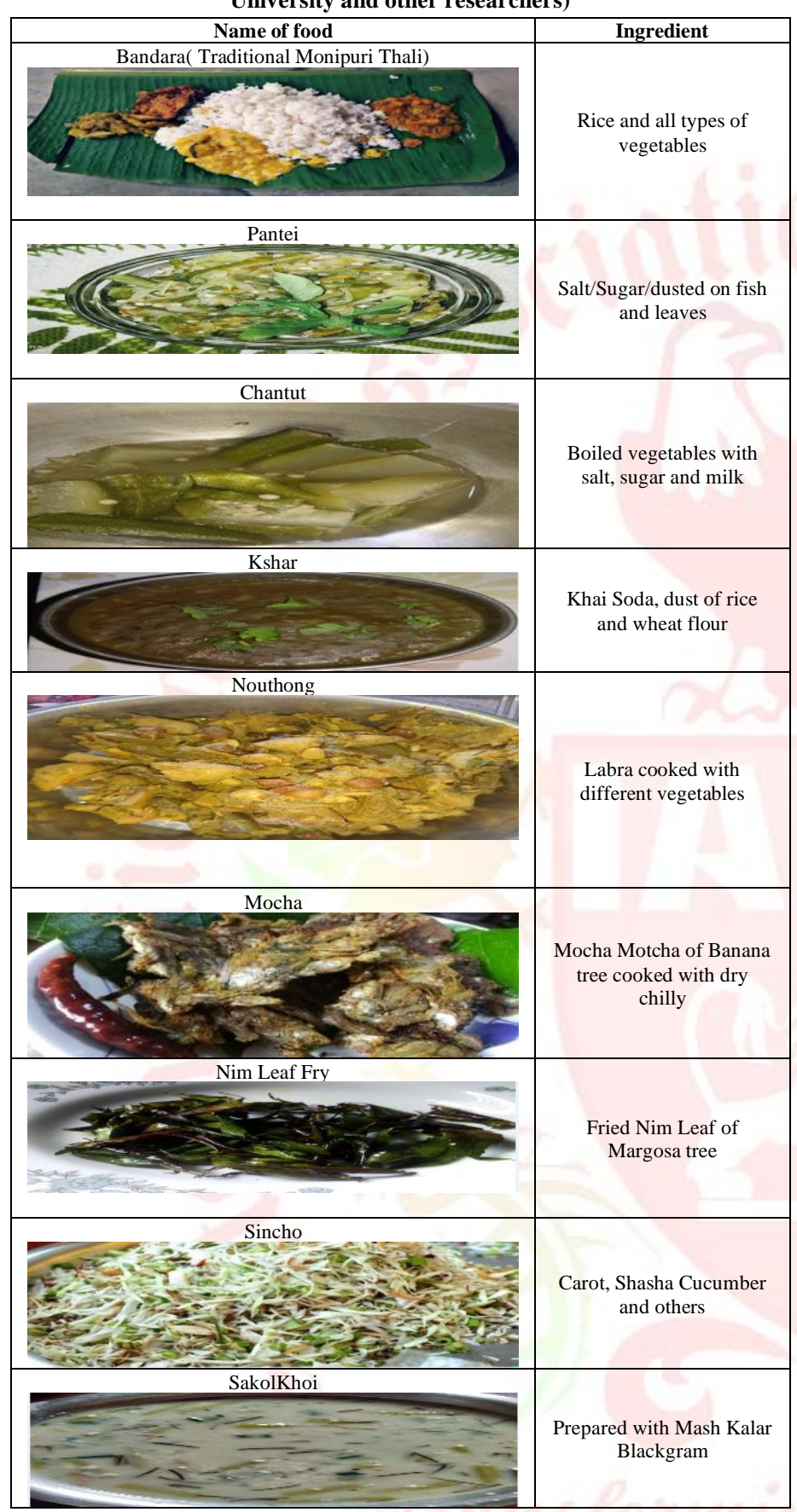

Due to the lockdown during COVID 19 people have been staying at home and more people are spending time with Facebook and other social media. Some groups known as Cheikh Kheikh post different types of cooked food using the names of these dishes in their languages. In this way their culture and language was maintained. Of the total participants of the Manipuri Communityin Sylhet City area 65\% think that the popularity of their language has increased during the lockdown. The young were more interested in learning the language. Before the lockdown very few Bengalis knew the name of their food.

At the same time the English Language is important during these challenging times. There are some words and instructions which have gained popularity among the people of the community. The researcher asked 15 Manipuris some English words and phrases like lockdown, social distance, washing hands, using masks, sanitizer and they all knew and understood these words.

Due to the limitation of movement the people have to stay at home and there is no opportunity to join social or public gatherings. While in the home domain they use their language. As a matter of fact, they have developed their knowledge of the language. In this way the lockdown has resulted in a more extensive use of the language.

\section{V.Conclusion}

The Manipuri community and culture in the Sylhet area of Bangladesh is culturally rich. It has a written orthography and a number of established books and journals. They can read and write the language. Their culture is also rich in traditional food and dance. Currently due to the lockdown due to COVID 19 and the need to stay at home the language is extensively used in the home domain. However, beyond the home domain there are few opportunities to learn the language in formal domains like schools and universities. The government should establish a system that at school level any student can learn any ethnic language course as an Elective or Compulsory course. Especially in the Sylhet area of Bangladesh there should be opportunities to learn the Manipuri Language in educational institutions.

\section{REFERENCES}

[1]. Article 3'The State Language" The Constitution of the People's Republic of Bangladesh.

Bdlaws.minlaw.gov.bd. Ministry of Law, The People's Republic of Bangladesh. Retrieved 25 April 2019.

[2]. Brenzinger, Matthias (ed.) Language Death: Factual and Theoretical Explorations with Special Reference to East Africa. Berlin/New York: Mouton de Gruyter. (1992).

[3]. Faquire, A.B.M. Razaul Karim. "Language Situation in Bangladesh". The Dhaka University Studies. 67: 
63-77. (December 2010). From The most spoken languages worldwide in 2019.

[4]. Super User. "History,." Home, (2002). Retrieved from http://www.manipuri.org/index.php/history. Accessed 21 Oct. 2020.

[5]. Al-Amin, Mohammad. "A Research Report on Culture of Manipuri Community A Study Conducted in Sylhet City." Academia.edu - Share Research (2015). Retrieved from www.academia.edu/13586778/A_Research. Accessed 22 Oct. 2020.

[6]. India, Cultural. "Manipuri." Information on Indian Culture, Tradition \& Heritage, (2020). Retrieve from www.culturalindia.net/indiandance/classical/manipuri.html. Accessed 20 Oct. 2020.

[7]. Mustgo TRAVEL. "Endangered Languages." MustGo.com, Mustgo TRAVEL, 10 Mar. (2019). Retrieved from www.mustgo.com/worldlanguages/endangered $\% 201 \mathrm{a}$ nguages/. Accessed 29 Oct. 2020.

[8]. Statista. "Most Spoken Languages in the World." Statista, (21 Feb. 2020), Retrieved from www.statista.com/statistics/266808/the-most-spokenlanguages-worldwide/. Accessed 27 Oct. 2020.

[9]. Krauss, ,M. The world's language in Crisis,Language 68:04-10.Language68:4-10. (1992).

[10]. Lakoff George. Women, Fire and Dangerous Things; What Catagories Reveal about ,the Mind: Chicago University Press. (1987).

[11]. Nettle, Daniel \& Suzanne Romaine.Vanishing Voices; The Extinction of World languages. Oxford University Press. (2000).

[12]. Nettle, Daniel and Suzanne Romaine Vanishing Voices: The extinction of the World's languages: Oxford University Press (2020). Persian Banglapedia Retrieved January 2018.

[13]. Snehangshu Shekhar Chanda. Endangered Languages in North Eastern Part of Bangladesh.Indian Languages and Culture(A Debate)-published by visva- Bharati). (2018).

[14]. State of the Rural Manipuris in Bangladesh;(Retrived from: http://www.ecdo- bd.org/?page_id=859).

\section{Endnotes}

${ }^{1}$ Sylhet Agricultural University, Sylhet, Bangladesh.

Email:sschanda2002@yahoo.com. 


\section{Manuscript Processing Footprints}

\section{A. Journal Volume/Issue Details}

This manuscript it published in Vol. 11 No. 012021 issue of IARS' International Research Journal (I'IRJ).

This is a Peer Reviewed (Refereed) International Journal archived with National Library of Australia.

The mentioned Volume/Issue is a special issue of the journal dedicated to Covid19 Pandemic Conditions across globe.

\section{B. Citation}

Chanda, Snehangshu Shekhar (2021) “COVID'S EFFECT ON AN ENDANGERED LANGUAGE IN THE SYLHET AREA OF BANGLADESH”, IARS' International Research Journal. Vic. Australia, 11(1). Available at: https://researth.iars.info/index.php/curie

\section{Author Declaration}

- The submission has not been previously published, nor is it before another journal for consideration (or an explanation has been provided in Comments to the Ed itor).

- The submission file is in OpenOffice, Microsoft Word, or RTF document file format.

- Where available, URLs for the references have been provided.

- The text is single-spaced; uses a 12-point font; employs italics, rather than underlining (except with URL addresses); and all illustrations, figures, and tables are placed within the text at the appropriate points, rather than at the end.

- The text adheres to the stylistic and bibliographic requirements outlined in the Author Guidelines.

- All Terms and Conditions about submission and publishing with IARS' International Research Journal on its official site and other sources have been gone through, understood, and accepted.

- With submission, this is declared that the submitter has all rights of the content, and to submit it. Also the submitter affirms that the rights of the submitted content are hereby transferred to IARS' international Research Journal and its parent company/publisher, without objections or conditions.

\section{Last Plagiarism Report}

Settings : similarity of 09 words in a row considered plagiarized.

Originality Assessment

\section{Overall Similarity: $13 \%$}

Date: Dec 20, 2020

Statistics: 453 words Plagiarized / 3383 Total words

Remarks: Low similarity detected, check your supervisor if changes are required. Sources

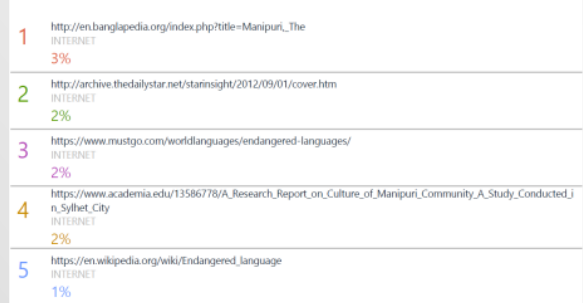

Exemption / Relaxation by Editor: Standard terms and Cited Text (relaxation of 5\%)

\section{E. Processing Track}

\begin{tabular}{|l|l|}
\hline Date of Submission: & 08 November 2020 \\
\hline Date of Referee/Review - 1: & 19 November 2020 \\
\hline Date of Referee/Review - 2: & 01 December 2020 \\
\hline Date of Additional Review: & NA \\
\hline Date of Acceptance: & 23 December 2020 \\
\hline Date of Publishing: & 08 February 2021 \\
\hline
\end{tabular}

